\title{
Metastasis: new perspectives on an old problem
}

\author{
Sandra Kraljevic Pavelic ${ }^{*}$, Mirela Sedic $^{2}$, Hrvojka Bosnjak ${ }^{3}$, Sime Spaventi ${ }^{4}$, Kresimir Pavelic $^{1}$
}

\begin{abstract}
Many hypotheses have been postulated to explain the intricate nature of the metastatic process, but none of them completely accounted for the actual biological and clinical observations. Consequently, metastasis still remains an open issue with only few metastasis-inducing proteins experimentally validated so far. Recently proposed novel metastatic model, where serial and parallel metastatic processes are adequately integrated, might help to bridge the current gap between experimental results and clinical observations. In addition, the identification, isolation and molecular characterization of cancer stem cells, a population of the cells within the tumour mass able to proliferate, self-renew and induce tumorigenesis, will shed new light on the complex molecular events mediating metastasis, invasion and resistance to therapy. Understanding the molecular basis of these tumour characteristics will usher in a new age of individualized cancer therapy. In this review article, we will provide a current overview of molecular mechanisms underpinning metastasis, and discuss recent findings in this field obtained by global molecular profiling strategies such as proteomics.
\end{abstract}

\section{Introduction}

Continuous technological advances in molecular biology have paved the way for new discoveries in cancer research. In particular, high-throughput profiling of cancer tissue specimens and body fluids has been extensively used in order to unveil specific molecular fingerprint of cancer [1-4]. Such strategy holds great promise for diagnostics purposes, as it might distinguish between different patients' prognostic subgroups (good/poor), which could provide the foundation for an individual therapeutic approach towards each patient (tailored therapy). However, in spite of these enormous efforts to elucidate cellular and molecular mechanisms underlying tumorigenesis, cancer still represents one of the deadliest scourges of the modern world.

Poor outcomes of current therapies, in particular poor prognosis for patients in advanced stages of solid tumours, have opened the possibility that tumour cells include a population of cells responsible for the initiation of tumour development, growth and its ability to metastasize and reoccur. Because these cells share some similarities with stem cells, they are referred to as cancer stem cells (CSCs). CSC are undifferentiated cells characterised by three major features: (1) potential to differentiate into several or all types of cells that are

\footnotetext{
* Correspondence: sandrakp@biotech.uniri.hr

'Department of Biotechnology, University of Rijeka, 51000 Rijeka, Croatia Full list of author information is available at the end of the article
}

produced by the original tumour; (2) self - renewal ability; and (3) capacity to maintain the 'stem cell pool' and the most mature tumour elements for unlimited time periods [5]. CSC could originate from tissue-specific stem cells and bone marrow stem cells, and somatic cells that undergo trans-differentiation processes, or can result from the fusion or horizontal gene-transfer processes. The self-renewal and differentiation ability of CSC gives rise to all tumour cell types, and thereby produces tumour heterogeneity. This relatively new perspective, the so-called "cancer stem cell" concept, casts new light on the origins of cancer.

The relationship and differences between normal and malignant stem cells remain unclear. In many instances, normal stem cells, tumour stem cells and metastatic stem cells share some common traits. Neoplastic stem cells were indeed shown to express similar antigen pattern and to display similar functional properties in comparison with normal stem cells. Moreover, it has been shown that for the maintenance and activation of both, normal stem cells and tumour stem cells, the Wnt/beta-catenin signalling, Notch and PTEN pathways are crucial [6]. Furthermore, growth of both, normal and neoplastic stem cells, is often mediated by the same cytokines [7].

Importantly, cancer/metastatic stem cells might be discerned from embryonic stem cells by their propensity to differentiate into the cell types within a particular
C Biomed Central

(c) 2011 Kraljevic Pavelic et al; licensee BioMed Central Ltd. This is an Open Access article distributed under the terms of the Creative Commons Attribution License (http://creativecommons.org/licenses/by/2.0), which permits unrestricted use, distribution, and reproduction in any medium, provided the original work is properly cited. 
organ (tumour). Therefore, it is tempting to believe that tumour arises from tissue stem cells, and that cellular components bearing stem-like properties govern tumour formation. If cancer arises from rare population of cells with stem-like characteristics, then it is plausible to presume that these stem cells differ from "normal" stem cells in high rate of mutations. It is widely accepted that stem cells undergo multiple mutations that are also required for carcinogenesis, most probably due to their long-lived nature [8]. Deregulation of self-renewal mechanisms (e.g. Wnt/beta-catenin, Notch and Hedgehog signalling pathways), which drive the stem cell expansion, might be the early key event precipitating the formation of CSCs in the particular tissue during the onset of carcinogenesis. This hypothesis is further corroborated by the fact that oncogenes may affect different stem cells and progenitor cells resulting in phenotypic differences in tumours, whereby it was shown that transgenes encoding components of the Wnt/beta-catenin signalling pathway preferentially induce mammary cancers from progenitor cells [9]. Activation of oncogenes and inactivation of some tumour-suppressor genes as the consequence of genomic instability might drive transformation of normal stem cells to CSCs. Several genes including AKT, TRAIL and CXCL12 are recognised as candidate genes for cancer stem cell progression and latent metastasis [10]. At last, cancer/metastatic stem cells might exhibit higher expression levels of some genes (e.g. CXCR4, SDF1, VEGF), antiapoptotic proteins (Bcl-2 family inhibitors of apoptosis) and transporter proteins (BCRP and P-glycoprotein), and might remain in the $G_{0}$ phase accounting for their resistance to chemotherapy.

Methods that unequivocally identify CSC via specific cell-surface protein markers might be diverse but have many pitfalls. In vivo assays using NOD/SCID mice are expensive and time consuming. Therefore, in vitro longterm growth assays including sphere-formation assays, serial colony-forming unit assays and label-retention assays are often used in order to screen for stem cell fractions or CSC-regulating compounds [6]. However, the major drawbacks of these methods include: (1) lack of tissue and tumour specificity; (2) inability to isolate CSCs according to the degree of tumour differentiation; (3) lack of species-specificity of CSC receptors and their ligands and homing receptors in the tissue environment; and (4) stem cell plasticity. At last, the general problem for all in vitro studies is the selection pressure upon the cultured cells, resulting in the selection of certain cell population permissible to survive and proliferate under specific conditions. Isolation of CSCs is also hampered by the lack of specific CSC antigens or typical antigen combinations not identified so far. These antigens might include regular stem cells antigens such as cytokine receptors, homing receptors (integrins, selectin-ligands, chemokine receptors, cytoadhesion molecules and ligands of matrix molecules such L1 or CD44) and various drug transporters $[5,6]$.

Metastases show a great variety of clinical presentations/manifestations, mostly in correlation with the primary tumour localization [11]. For example, breast cancer metastases can remain latent in the several years follow-up after surgical removal of the primary lesion, whereas metastases in patients with detected pancreatic cancer and small-cell lung carcinoma are often widespread at the time of cancer diagnosis. Furthermore, glioblastoma is locally progressive and invasive, but rarely affecting secondary sites outside CNS. The efficacy of common treatment regimens including radical excision of the primary tumour followed by radiotherapy and/or chemotherapy is limited and often fails to cure the patient. Recent findings imply that some treatments (e.g. irradiation at certain regimen, Taxol etc.) do not target the CSCs responsible for tumour development. Moreover, such treatment might have a completely opposite effect, e.g. to produce more cancer cells capable of metastasizing [12-14]. Indeed, it is widely accepted that CSC have a dormant nature and abundantly express drug transporters [15], which could provide a plausible explanation for resistance to standard chemotherapy known to target dividing cells. Consequently, $90 \%$ of deaths of the patients with solid tumors are attributed to local invasion and distant metastases [11].

\section{Metastatic model - "serial" or "parallel"?}

The molecular mechanisms of metastasizing are still covered by the veil of mystery. The application of genomic profiling methods (DNA microarray) combined with either animal models of metastasis or laser capture microdissection (LCM) providing in vivo insight into molecular processes underlying metastatic progression have fostered the research of its complex molecular nature. So far, the so-called "serial" model of clonal progression has been generally accepted explaining that metastatic cells originate from the primary tumour and represent the end stage of tumorigenesis. Although the metastatic genotype contains additional genetic mutations, its spectrum of aberrations is thought to be similar to that found in the primary lesions [16], as augmented by the findings of kariotypic and genomic analyses of the breast, bladder, colon and kidney malignancies [17-24]. Surprisingly, some of these studies indicate the existence of metastases with lack of (without) genetic similarity to the primary tumour $[18,20,25]$. Bissig et al. [18] showed that $30 \%$ of renal cell metastases have almost completely different genotype in comparison with the primary lesion cells isolated from the same patient. Furthermore, a genomic study of metastatic breast cancer [20] presented a significant amount of 
breast metastases, which do not show strong clonal resemblance to the tumour of primary origin. Finally, the analysis of metastatic lesions at several sites in the same individuals showed a substantial evolutionary divergence between metastatic lesions and primary tumour, as well as between the metastases themselves.

Schmidt-Kittler et al. [25] reported unexpected results providing novel insight into metastatic progression. In this study, patients were divided into two groups according to clinical presence or absence of metastatic dissemination (M0 - no metastatic disease; M1-metastasis positive). The results of comprehensive genomic analyses of the primary tumour specimens and single cytokeratinpositive $(\mathrm{CK}+)$ epithelial cells from the bone marrow of the corresponding patients were as follows: (1) the CK+ cells from M0 patients showed about half as many genomic aberrations as those from M1 patients; and (2) most of the CK+ cells from M0 patients showed little similarity to the primary tumour. To sum up, cells from M0 patients showed whole chromosome copy number aberrations, while cells from M1 patients showed sub-chromosomal changes typical for aberrations that appear during telomere crisis. The authors suggest that eventual appearance of clinically detectable metastases in M0 patients could be a consequence of early disseminated cells, which evolve and pass through crisis independently of the primary tumour. Due to slow evolution of these disseminated cells, as well as their persistence during a long period, the results of this study offer an explanation for the appearance of clinically evident metastatic disease years after treatment of the primary tumour that was presumed to be successful and curative [16]. A comparison of genetic fingerprints among disseminated cells from M0 patients with those from metastatic cells that will arise during the follow-up after primary tumour treatment is of utmost importance for the "parallel" theory. Similarly, Hüsemann et al. [26] showed that cancer cells can spread systematically from earliest epithelial alterations in HER-2 and PyMT transgenic mice and from ductal carcinoma in situ (DCIS) in women, thus providing additional evidence that supports the novel outlook on the onset of metastatic spreading and its parallel progression (evolution) during tumorigenesis. This "parallel" concept is, nevertheless, based on several pioneering studies $[27,28]$, the first one being the experimental documentation in human leukemias [29] that shaped the concept of 'cancer stem cells'.

Since initiation of metastasis process is inherent to CSCs, the metastatic progression should be thus studied as an independent and "parallel" process in tumorigenesis governed by the so-called EMT (epithelial to mesenchymal transition) that occurs among tumour cells. The majority of tumours are epithelial but exert mesenchymal characteristics. During tumour invasion, tumour cells move from the primary tumour site and, similarly to the cells in epithelia during normal embryonic development, lose epithelial characteristics and cellto-cell contacts, and acquire the mesenchymal gene expression [30]. Such cells are then capable of invading distant sites (Figure 1). The changes occurring in the cell-to-cell adhesions forces as well as in the cytoskeletal cortex association to plasma membranes are therefore central to the invasion, migration and intravasation of tumour cells. According to this, epithelial cells might be somehow "induced" to become metastatic by several factors such as chemokine CCL5 [31] and transcription factors FOXC2, Twist, Snug, Snail and ZEB1 [13,32] that were shown to drive the EMT programme. The EMT process might account for some similarities found between embryonic stem cells and the stem cell-like traits in neoplastic cells. One must, however, always have in mind that not every EMT-inducing factor discovered will necessarily elicit a stem-like profile.

As recently nicely reviewed by Hurt and Farrar [33], the question remains whether the existing CSCs or rather those cells that escaped the primary tumour and acquired the stem cell-like phenotype through the EMT process, induce distant metastases. Further research based on the use of powerful imaging methods and in line with the in vivo study performed by Condeelis et al. [34] showing the convincing images of individual cells delaminated from primary tumours, will be needed to

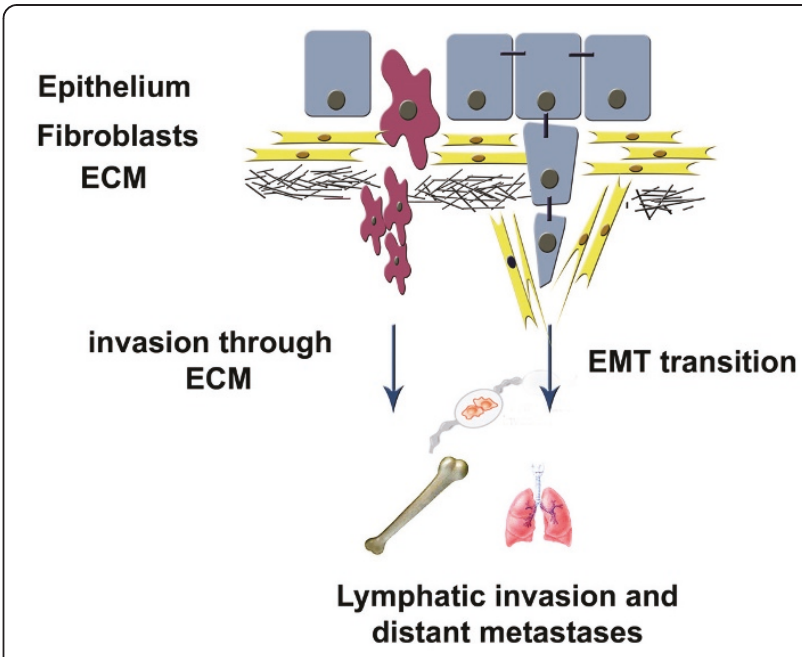

Figure 1 The epithelial-mesenchymal transition (EMT) occurs at the primary tumour site where epithelial cells lose tight junctions and apico-basal polarity. The remodelling of the cytoskeleton occurs as well. The invasion process through the extracellular matrix (ECM) is frequently led by so called tumourassociated fibroblasts. EMT can induce stem-cell-like properties in cells. The question still remains whether the existing cancer stem cells or rather those cells that escaped the primary tumour and acquired the stem cell like phenotype through the EMT process induce distant metastasis. 
resolve this issue. Taking all this together, new therapeutic modalities will be required to target independently evolved metastatic cells after early separation from the primary tumour, which will lay the groundwork for further improvement of therapeutic efficacy.

\section{Organ tropism and metastatic gene signature}

The molecular basis of organ tropism, one of the main features of metastasis, is still obscure. It has been well documented that different types of cancer produce metastases at preferred secondary sites, depending on the tissue susceptibility to specific metastatic cells. Bone metastasis is often associated with breast, prostate or lung cancer, while it is rarely detectable in patients with diagnosed colorectal cancer [35]. This preferential development of macrometastases at distant secondary organs can be partially explained by the pattern of blood flow. Nevertheless, molecular interactions between metastatic cells (seeds) and stromal microenvironment (soil) have been proven to mediate efficiency of metastatic formation and its tissue specificity [35]. When it comes to the role of tumour microenvironment in tumour dissemination, early changes observed in tissue before evidence of carcinogenesis might be critical for tissue-specific metastasis. For example, the inflammatory response, matrix remodelling and increase in reactive oxygen species often precede tumour metastasis. Accordingly, it has been recently shown that alteration in the expression of metalloproteinase 9 precedes metastasis in lung [36]. The same studies also showed that arrival of bone marrow-derived hematopoietic progenitors expressing vascular endothelial growth factor receptor 1 in distant sites, which fosters inflammation and sustains tumour growth, represents some of the early changes present in the local microenvironment and necessary for metastases to occur [37].

Genetic and phenotypic characteristics of tumours have also been studied as factors linked to organ-specific metastases [38-40]. Kakiuchi et al. [39] reported differential gene expression profiles for lung, liver, kidney and bone metastases. Another research group [38] investigated metastatic potential of human breast cancer using MDA-MB-231 cell line, originally derived from the pleural effusion of a patient with metastatic dissemination. After injection into immunodeficient mice, metastases were detected in bone and adrenal medulla. Subsequently, human cells were re-isolated from the osteolytic bone metastases, and sublines with high metastatic potential were observed. Microarray profiling of these sublines revealed that the gene expression signatures directly correlated with metastases. The authors were able to distinguish cells with tendency to disseminate to bone or adrenal medulla, as the two groups showed differential gene expression patterns. A set of
CXCR4, IL-11, CTGF and MMP1 genes, if co-expressed with the gene encoding osteopontin, correlated with bone-specific metastatic potential. Each of these genes, when expressed alone, failed to cause high metastatic potential. Thus, the set of genes found in the bone metastasis signature seems to be a causative factor in metastasizing to the bone. Furthermore, Minn et al. [40] identified a set of 54 genes with differential expression in lung-tropic breast cancer sublines in comparison with bone-tropic lines. The identified set of 54 genes in lungtropic gene signature is probably not the only gene set responsible for metastasizing to the lungs, because a small amount of investigated primary tumours expressed this specific signature. Therefore, it is logical to presume that other lung-tropic metastatic signatures are yet to be discovered. Recent gene expression profiling studies revealed an association between Src pathway activity and late-onset bone metastasis in breast cancer, which is independent of hormone receptor status and breast cancer subtype [10]. Src activity was shown to be required for CXCL12 activation of the AKT cell survival pathway and for the resistance of metastatic breast cancer cells to the pro-apoptotic effects of TRAIL, both of which are predominantly expressed in the bone metastasis microenvironment. In view of these findings, targeting Src signalling pathway might provide a novel strategy to suppress the survival of disseminated cancer cells.

Although it is widely accepted that some primary tumours are predestined to metastasize to specific organ, it is still unclear when and how exactly they acquire organ-tropic gene signatures [41]. Furthermore, the complex multistep nature of metastasis process suggests that vast arrays of genes are responsible for its regulation. Addressing the question of metastatic prediction, recent analyses of human cancer specimens using DNA microarray technology suggest that patients can be divided into prognostic subgroups, based on the "good" or "poor" gene expression signature of the primary tumour, which predicts the risk of metastasis appearance after tumour resection, particularly evaluated in breast cancer $[4,42,43]$. Traditionally, in clinical practice, the potential of its metastatic recurrence is in correlation with primary tumour size and histological grade. In a recent study, Ramaswamy et al. [44] compared gene signatures of primary adenocarcinomas and metastases from a similar set of adenocarcinomas. Their analysis revelaed a "metastatic gene signature" common to many different tumour types. When detected in some primary tumours, this signature indicated its pre-existed tendency to metastasize and, therefore, had a significant prognostic value. Nevertheless, evaluation of this metastatic signature once the primary tumour is diagnosed distinguishes tumours with local growing potential from those preconfigured to disseminate to distant sites $[44,45]$. However, it remains 
unclear whether these metastatic signatures are causative factors in metastatic spreading or indirect indicators of metastatic potential [46].

Besides screening for genes linked to metastasis organ tropism, the stem cell theory might provide an additional explanation for this phenomenon. In fact, it has been well documented that CSCs express a G-protein-coupled seven-span transmembrane receptor CXCR4 on their surface similarly to normal stem cells for different organs/tissues [47]. Facts about the role of chemokines, small pro-inflammatory chemoattractant cytokines that bind to G-protein transmembrane receptors of target cells, in mediating cell trafficking might additionally illuminate how metastases are attracted to specific organs. For example, a stromal-derived chemokine SDF-1 exclusively binds to CXCR4 and is highly expressed in lymph nodes, lung, liver or bones. Therefore, metastasis of CXCR4+ tumour cells might be driven specifically to these organs through the SDF1-CXCR4 axis [47]. This assumption is augmented by the findings revealing that several CXCR4+ cancers such as breast, ovarian and prostate cancer metastasize to bones from bloodstream in a SDF-1 dependent fashion $[47,48]$. However, possible therapeutic strategies based on modulation of the SDF1-CXCR4 axis or other chemokines involved in stem cell trafficking should be carefully considered, as this signalling pathway is normally involved in the trafficking of stem cells.

\section{Molecular mechanisms of metastasizing}

Metastasis is apparently central in terms of clinical management of cancer, as the preponderance of patients' deaths are associated with disseminated disease rather than the primary tumour. Moreover, patients with small primary tumours and node negative status (T1N0) at surgery often (15\% to $25 \%$ ) develop distant metastases [49]. As summarized in this paper, recent literature data support the concept of metastasis as a second disease imposed on the primary tumour, where the outcome of metastasis is determined by the interplay between the specific subpopulation of metastatic cells and host homeostatic factors in specific organ microenvironment including vasculature. However, over the past decades, the so-called progression model has been widely accepted among clinicians and researchers. This model depicted metastasis as a result of several consecutive mutational events occurring either in subpopulations of the primary tumour or disseminated cells, and yielding a small fraction of cells that acquire full metastatic potential. Recently, several microarray studies have prompted reexamination of the progression model, as they enable identification of gene signatures that can distinguish metastatic from non-metastatic tumours, and postulate that metastatic propensity is established early in oncogenesis [44,45]. Accordingly, metastatic genes can be classified into several groups: metastasis initiation genes, metastasis progression genes and metastasis-virulence genes [11]. Metastasis initiation genes provide an advantage in a primary tumour and enable tumour cells to enter the blood-flow. Most genes mediating tumour cell motility, invasion or angiogenesis belong to this group. This class includes genes involved in EMT and caspase 8, whereby loss of caspase 8 function protects tumour cells from programmed death due to release of integrin-regulated anchoring at the invasive front $[30,50,51]$. The second class of metastatic genes, specified as the metastasis progression genes fulfil some rate-limiting functions in primary tumour growth and other specific functions in metastatic colonization. These genes can be found within organ-tropic gene signatures, thus causing specific advantage restricted to particular distant organ. Nevertheless, while metastasis-virulence genes participate in metastatic colonization due to selective advantage in secondary sites, they do not affect the primary tumour development [11]. Therefore, these genes promote aggressiveness of metastatic tumour cells at the level of colonized distant organs. Recent study dealing with organ-specific metastases in breast cancer reported on the lung-tropic metastatic gene set comprising 54 genes, among which only 18 were expressed in primary tumours. These results provide an evidence for the existence of metastasis progression genes and metastasis virulence genes [40,52]. Both groups of genes enable circulating tumour cells to colonize the lungs. The 18 genes expressed in the primary tumour induce primary tumorigenesis, leading to the larger tumour size at the time of diagnosis. Due to vascularremodelling programme, three out of those 18 genes (EREG, COX2 and MMP1) facilitate tumour angiogenesis and intravasation in mammary tumours. In addition, they act as a mediator in tumour cells extravasation from the lung capillaries. Accordingly, the EREG, COX2 and MMP1 genes are classified as metastasis progression genes.

Introduction of improved molecular research methods has opened new chapter in metastasis research by specifically disclosing some of the underlying molecular events in metastatic progression. Molecules which play an important role in processes involving cell-cell adhesion, migration, proteolysis, chemotaxis, angiogenesis and signal transduction have been investigated with aim to decipher their activity in evolution of metastasis [35]. Five candidate metastasis genes, namely CXCR4, IL-11, CTGF, MMP1 and osteopontin from the bone metastasis signature reported by Kang et al [38] encode secreted cytokines or cell surface receptors, which is consistent with traditionally accepted idea that metastasis formation is a consequence of pathological interactions between tumour cells and stromal microenvironment. The evidence for this widely accepted theory is provided by $\mathrm{Hu}$ et al. [53], who used 
a xenograft model of human DCIS and primary human breast tumours. The authors found that myoepithelial cells and fibroblasts mediate the transition from DCIS to invasive carcinoma. In the absence of normal myoepithelial cells, co-injection of fibroblasts promoted progression of in situ to invasive carcinoma. On the contrary, co-injection of normal myoepithelial cells effectively suppressed tumour weight, despite presence of progression-promoting fibroblasts. The obtained results were not the upshot of permanent genetic aberrations in the epithelial tumour cells. Furthermore, TGF- $\beta$ and Hedgehog signalling were recognized to have a critical role in breast tumour progression, while decreasing TGF- $\beta$ and Hedgehog pathway activity via TGFBR2/SMAD4 downregulation and Gli2 expression resulted in the loss of myoepithelial cells and accelerated invasion.

Even if a wealth of evidence supports this model, some paradoxes still remain. First, in many tissues where tumours arise, normal mature cells have a short lifespan. Consequently, the chances to accumulate mutations required for tumour development are rather limited. Secondly, patients diagnosed with disseminated disease with unknown primary cancer metastatic disease have no clinically detectable primary tumour or only a small, well differentiated lesion that is found at autopsy [54]. Furthermore, although variant clones with high metastatic capacity can be identified in populations, it is frequently observed that these variants revert to a lowmetastatic capacity after several generations $[55,56]$. The so-called transient metastatic compartment model proposed by Weiss et al [57] suggests that all viable cells in a tumour might acquire metastatic capacity as explained by the progression model, but due to their position in the primary tumour and random epigenetic events, only a small fraction of these cells are competent to metastasize at a given moment in time. Thus, not all cells within a tumour preserve the capacity to disseminate to secondary sites as a result of accidental, or microenviromentally induced epigenetic events or inadequate access to vasculature. However, this model fails to explain the clonal nature of metastases. If every cell had a metastatic ability modulated only by momentary epigenetic events, then it would be less likely that significant proportions of secondary tumours would appear to be of clonal origin.

Another intriguing theory, the so-called cell fusion theory, explains that the acquisition of metastatic phenotype occurs when a healthy migratory leukocyte fuses with a primary tumour cell. Such a 'hybrid' has the innate blood cell ability to migrate through the body while still keeping the uncontrolled cell processes as occurring in the tumour cells [58,59]. Interestingly, the fusion of genetic and cytoplasmic material between cells of different origins is an important physiological process during development. Generally, cell fusion and horizontal gene-transfer events could be important in the development of the CSCs [60]. Substantiating these theses, the in vitro fusion of cells was proved to produce subclones with varying metastatic potentials $[61,62]$, and over 30 reports confirming cancer cell fusion in animal tumour models have been published so far $[63,64]$. In addition, a number of factors such as cellular or viral fusion proteins or environmental factors may provoke cell fusion of tumour and normal cells. Such fused cells will probably die or become quiescent. Nevertheless, there is a small fraction that will maintain the ability to proliferate and generate malignant cells. It has been shown that endothelial cells in solid tumours might be aneuploid with multiple chromosomes and multiple centrosomes, implying the possibility of cell fusion between tumour cells and endothelial cells [65]. This theory has yet to be confirmed in humans as well.

\section{Technological advances in metastasis research: proteomics}

Global transcriptome profiling of cancer has undoubtedly improved our knowledge of tumour biology, and has led to the discovery of novel therapeutic and imaging targets, as well as potential prognostic and predictive biomarkers for diverse cancer types. However, transcriptomics can predict neither the expression level nor the functional status determined by folding, post-translational modifications, cellular localization and molecular interactions of the key signalling molecules in complex protein networks integral to cancer pathogenesis. For example, how exactly and when the EMT process and other pro-survival signalling cascades in cancer cells are triggered, still remains to be elucidated. Cancer may be genetically based, but on the functional level, it is a proteomic disease [66], because tumour progression, invasion, and metastasis depend on the functional activity of many proteins, such as growth factors and proteases.- Consequently, molecular oncologists have been turning more to proteomics technologies (Table 1) as to identify novel protein biomarkers specifically associated with metastatic transition, and to decipher signal transduction pathways that propel the cells down the road towards metastasis. Such technological approach should provide an early detection and prediction of metastatic processes, and reveal novel targets for drug development and therapeutic intervention. There is now an enormous wealth of literature data on employing proteomics in metastasis research covering practically all tumour types, and discovered biomarkers might be correlated with the metastatic process and/or cancer stem cell phenotype. Some recent examples will be briefly discussed below.

2-DE followed by MALDI-TOF MS analysis represents the workhorse of the vast majority of published 
Table 1 Overview of the most common proteomics technologies in the research of tumour invasion and metastasis

\begin{tabular}{|c|c|c|c|c|c|}
\hline $\begin{array}{l}\text { Proteomics } \\
\text { method }\end{array}$ & Abbreviation & Basic principle & Biological Application & Advantages & Limitations \\
\hline $\begin{array}{l}\text { Two-dimensional } \\
\text { gel electrophoresis }\end{array}$ & 2-DE & $\begin{array}{l}\text { Proteins are first resolved } \\
\text { by their isoelectric points, } \\
\text { and then by molecular } \\
\text { weights }\end{array}$ & $\begin{array}{l}\text { Separation of proteins in } \\
\text { complex biological } \\
\text { samples }\end{array}$ & $\begin{array}{l}\text { High resolution Very } \\
\text { sensitive } \\
\text { Direct detection of } \\
\text { post-translational } \\
\text { modifications }\end{array}$ & $\begin{array}{l}\text { Limited automation } \\
\text { Problematic gel-to-gel } \\
\text { reproducibility } \\
\text { Problematic recovery of } \\
\text { hydrophobic and large } \\
\text { molecular weight proteins } \\
\text { Limited dynamic range of } \\
\text { detection }\end{array}$ \\
\hline
\end{tabular}

Two-dimensional 2D-DIGE difference gel electrophoresis

Matrix assisted laser desorption MALDI-TOF ionisation time-offlight mass spectrometry

\section{Multidimensional MudPIT}

protein

identification

technology

$\begin{array}{ll}\text { Surface enhanced } & \text { SELDI-TOF } \\ \text { laser desorption } & \text { MS } \\ \text { and ionization time- } \\ \text { of-flight mass } \\ \text { spectrometry } \\ \text { (ProteinChip } \\ \text { Technology) }\end{array}$

Samples are labelled with two spectrally distinct fluorescent cyanine dyes, and run on the same 2-DE gel; the two gel images corresponding to each dye scan are then overlaid, and the intensities of paired spots are compared across the gel images

Tryptic digests of sample proteins are co-crystallized with matrix, and spotted onto MALDI plate; ionization occurs by pulsed laser radiation primarily absorbed by the matrix causing desorption and ionization of the analyte; the resulting peptide ions are directed into TOF mass analyzer, where peptide masses are measured by determining the time required for the ions to traverse the length of the flight tube and reach detector

Mixture of tryptic peptides is resolved by the microcapillary column packed with reversedphase resin followed by strong cation exchange resin; peptides are eluted directly from the column into the mass spectrometer to be rapidly analyzed

\section{Protein solutions are} applied to the spots of ProteinChip Arrays that contain either chemically (anionic, cationic, hydrophobic, hydrophilic, or metal ion) or biochemically (immobilized antibody, receptor, DNA, enzyme, etc.) active surface retaining proteins according to their specific physicochemical properties; after adding matrix solution to bound proteins, the latter are ionized with nitrogen laser and their molecular masses measured by TOF mass analyzer. As a result, unique protein abundance profiles of species bound to the chip surface are obtained.
Quantification of the differences in protein expression between different samples

High sensitivity Accurate quantitation Good reproducibility
Expensive fluorophores, equipment and software
Protein identification Amino-acid sequencing Determination of the type and position of posttranslational modifications

Produces less raw data than other MS

techniques

Data are relatively easy to interpret since most peptides carry only one charge and are present as a single peak in a spectrum
Large-scale protein analysis of complex biological mixtures

Identification of protein complexes

Determination of posttranslational modifications Quantitative analysis of protein expression

Biomarker discovery Characterization of proteinprotein and protein-DNA interactions and posttranslational modifications (glycosylation and phosphorylation)
Detects proteins of wide range of $\mathrm{pl}$, abundance and subcellular distribution Employed directly on crude samples

Easily automated High resolving power High sensitivity

Suitable for crude biological samples (body fluids, cells) High-throughput capability High sensitivity Detects proteins with molecular weights lower than 6-kDa High precision and reproducibility
Time-consuming Requires experienced personnel Does not detect protein activity nor interactions Limited throughput Generates the vast stream of raw data

Additional MS analysis needed for determining the identity of differentially expressed protein species
Requires previous separation of protein mixture smpered identification small acidic and integral membrane proteins 
Table 1 Overview of the most common proteomics technologies in the research of tumour invasion and metastasis (Continued)

\begin{tabular}{|c|c|c|c|c|c|}
\hline $\begin{array}{l}\text { Isotope-coded } \\
\text { affinity tags }\end{array}$ & ICAT & $\begin{array}{l}\text { Two different protein } \\
\text { samples are labelled at } \\
\text { cysteines with the } \\
\text { isotopically light and heavy } \\
\text { ICAT reagents, combined } \\
\text { and digested with trypsin; } \\
\text { ICAT-labeled peptides are } \\
\text { isolated by avidin affinity } \\
\text { chromatography and } \\
\text { analyzed by HPLC coupled } \\
\text { to a tandem mass } \\
\text { spectrometer; the ratio of } \\
\text { ion intensities from co- } \\
\text { eluting ICAT-labeled pairs } \\
\text { permits the quantification, } \\
\text { while a subsequent } \\
\text { MS/MS scan provides the } \\
\text { protein identification }\end{array}$ & $\begin{array}{l}\text { Sequence identification } \\
\text { and quantification of } \\
\text { proteins in complex } \\
\text { mixtures } \\
\text { Analysis of protein changes } \\
\text { in specific subcellular } \\
\text { fractions }\end{array}$ & $\begin{array}{l}\text { Selects only cysteine- } \\
\text { containing peptides } \\
\text { and thus effectively } \\
\text { reduces the complexity } \\
\text { of the peptide mixtures }\end{array}$ & $\begin{array}{l}\text { Incomplete proteome } \\
\text { coverage (10-20\% of the } \\
\text { whole cell proteome) }\end{array}$ \\
\hline $\begin{array}{l}\text { Laser-capture } \\
\text { microdisscetion }\end{array}$ & LCM & $\begin{array}{l}\text { A stained tissue slide is } \\
\text { placed under a microscope, } \\
\text { and a specific } \\
\text { thermoplastic polymer film } \\
\text { is placed over the tissue; } \\
\text { the cells of interest are } \\
\text { shot by an infrared laser } \\
\text { pulse, which melts and } \\
\text { fuses the film around the } \\
\text { targeted cells; the cells } \\
\text { embedded in the polymer } \\
\text { are lifted away from the } \\
\text { remaining tissue }\end{array}$ & $\begin{array}{l}\text { Isolation of pure cell } \\
\text { populations from } \\
\text { heterogeneous tissue } \\
\text { sections prior to proteomic } \\
\text { analyses focused on the } \\
\text { investigation of novel } \\
\text { biomarkers and drug } \\
\text { targets }\end{array}$ & $\begin{array}{l}\text { High-throughput } \\
\text { Reduces sample } \\
\text { heterogeneity } \\
\text { Increases the specificity } \\
\text { of signals obtained in } \\
\text { downstream protein } \\
\text { analysis }\end{array}$ & $\begin{array}{l}\text { Requires competency in } \\
\text { identifying the cells of } \\
\text { interest } \\
\text { Limited timeframe for } \\
\text { microdissecting fresh } \\
\text { frozen tissue. }\end{array}$ \\
\hline $\begin{array}{l}\text { Reverse-phase } \\
\text { protein microarrays }\end{array}$ & RPMA & $\begin{array}{l}\text { Cell lysates are arrayed on } \\
\text { nitrocellulose-coated glass } \\
\text { slides binding denatured } \\
\text { proteins; the slide is } \\
\text { probed with a single } \\
\text { antibody specific for an } \\
\text { antigen of interest; upon } \\
\text { signal development and } \\
\text { imaging, the relative } \\
\text { proportion of the analyte } \\
\text { protein molecules can be } \\
\text { compared between test } \\
\text { samples on the array }\end{array}$ & $\begin{array}{l}\text { Functional mapping of } \\
\text { known cell-signalling } \\
\text { networks or pathways } \\
\text { Characterization of protein- } \\
\text { protein, protein-DNA, and/ } \\
\text { or protein-RNA interactions }\end{array}$ & $\begin{array}{l}\text { High-throughput } \\
\text { Requires low sample } \\
\text { volume } \\
\text { Extremely sensitive } \\
\text { analyte detection } \\
\text { Good reproducibility, } \\
\text { sensitivity, and } \\
\text { robustness }\end{array}$ & $\begin{array}{l}\text { The lack of availability of } \\
\text { high-quality, specific } \\
\text { antibodies } \\
\text { Hampered analysis of low- } \\
\text { abundance post- } \\
\text { translational events }\end{array}$ \\
\hline
\end{tabular}

proteomics studies on metastasis research, and this approach has proved effective in measuring protein expression patterns within cells, tissues and bodily fluids uncovering many novel metastasis-related proteins, such as chloride intracellular channel 1 (CLIC1). CLIC1 was specifically correlated with metastasis of gallbladder carcinoma, the most frequent form of bile duct cancer, as its expression was significantly up-regulated in the highly metastatic gallbladder cancer GBC-SD18H cell line when compared to the poorly metastatic GBCSD18L cell line [67]. In addition, the overexpression of CLIC1 promoted cell motility and invasion of GBCSD18L cells, while RNA interference of CLIC1 remarkably decreased cell motility and invasive potency of GBC-SD18H cell line. Similarly, proteomics profiling of tumor tissues from gastric cancer revealed CLIC1 to be significantly up-regulated in $67.9 \%$ of the patients [68]. This study revealed significant correlation between elevated expression of CLIC1 and lymph node metastasis, lymphatic invasion, perineural invasion, advanced pathological stage and poor survival in gastric cancer, which highlights the role of CLIC1 in tumor invasion and metastasis in gastric cancer.

S100A11 protein is a calcium-binding protein implicated in a variety of biological functions such as proliferation and differentiation, whose relation with tumor progression and invasion was substantiated by recent proteomics studies. Tian et al. [69] carried out comparative 2-DE/ MALDI-TOF MS analysis of non-metastatic and highly metastatic non-small cell lung cancer (NSCLC) cell lines and found S100A11 to be specifically up-regulated in the metastatic cell line. Immunohistochemical staining of 65 
primary NSCLC tissues and 10 matched local positive lymph node specimens confirmed that the over-expression of S100A11 in NSCLC tissues was significantly associated with higher tumor-node-metastasis stage and positive lymph node status, implying regulatory role of this protein in promoting invasion and metastasis of NSCLC [69]. Using the same proteomics strategy, S100A11 was also reported to be up-regulated in metastatic hepatocellular carcinoma (HCC) tissues [70], and to rise in the expression level with the progression of colorectal cancer [71]. In view of these studies, S100A11 protein might be considered as useful candidate molecule for early diagnosis and intervention of NSCLC, HCC and colorectal metastases.

The development of fluorescent dye labels allowing the comparison of two different samples on a single gel referred to as 2-D fluorescence difference gel electrophoresis (2-D DIGE) has improved reproducibility, more accurate quantitation and spot statistics between gels in comparison with conventional 2-DE. This method was successfully applied to screening potential biomarkers for early detection of prostate cancer and lung squamous carcinoma metastases. Pang et al. [72] analyzed protein samples from localized and lymph node metastatic prostate cancer (LNM PCa) as well as benign prostatic hyperplasia tissues, and found increased expression of e-FABP5, MCCC2, PPA2, Ezrin and SLP2 along with reduced expression of SM22 in LNM PCa tissues. Importantly, e-FABP5 levels were significantly increased in the sera of patients with LNM PCa. These findings were in line with the previous studies revealing an over-expression of e-FABP5 protein in $\mathrm{PCa}$ tissues [73]. Overexpression of e-FABP5 was shown to induce metastasis by up-regulating VEGF, which plays a crucial role in the metastatic cascade [74]. Therefore, increased e-FABP expression is a possible target to inhibit the malignant progression of prostate cancer cells. Using the same technique, Yao et al. [75] compared the protein profiles between laser capture-microdissected (LCM) lung squamous carcinoma (LSC) cells with and without lymph node metastasis (LNM), and found rise in the expression level of HSP27, Annexin A2, and CK19, whereas 14-3-3 $\sigma$ had reduced expression in LNM LSC. Additional immunohistochemical analyses confirmed that these proteins are indeed correlated with several clinicopathological variables and prognosis of LSC.

The increasing use of high-throughput platforms for the analysis of protein expression levels driven by technological improvements in mass spectrometry and array-based technologies has pushed the boundaries of clinical oncoproteomics. Serum protein pattern profiling by ProteinChip Technology (SELDI-TOF MS) has emerged as novel approach to discover protein signatures capable of discriminating patients with primary cancer from those with metastasis, as demonstrated by several recent studies on laryngeal squamous cell carcinoma [76], colorectal [77], ovarian [78], lung [79], prostate [80], breast [81] and gastric cancer [82]. Collectively, these studies clearly showed diagnostic and prognostic value of ProteinChip technology. In addition, Goncalves et al. [83] used this proteomics approach on a high-risk early breast cancer population receiving standard adjuvant chemotherapy, and managed to identify a post-operative serum proteomic profile that might predict metastatic relapse. Currently, there are no satisfactory screening and early diagnostic strategies for metastatic cancer. Due to its quantification capability and reproducibility, SELDI-TOF MS represents a serious candidate tool for rapid and accurate high-throughput screening of cancer patients.

Major breakthrough in metastasis research represents the combination of LCM and protein microarray technologies, which has been applied to the analysis of human metastatic breast and ovarian cancer tissue samples in phase II clinical trials at the National Institutes of Health National Cancer Institute [84]. Similarly, Sheehan et al. [85] utilized reverse phase protein microarray (RPMA) technology to profile a matched cohort of primary and metastatic ovarian carcinomas using phosphorylation-specific antibodies. Strikingly, the metastatic signatures were clearly very different from the primary tumor taken at the same time at surgery, and these fingerprints appeared to be virtually patient-specific, which underscores the critical need for patient-tailored therapy designed to specifically target the disseminated cells. The same study revealed several phosphorylated proteins that were differently expressed between primary and metastatic tissues, including the phosphorylated forms of c-Kit, Ask, myristoylated alanine-rich $C$ kinase substrate, I $\kappa \mathrm{B} \alpha$, and Ras-GRF [85]. Importantly, metastasis correlated with activation of c-Kit, which was previously demonstrated to pertain to advanced stage and chemotherapy resistance in serous ovarian carcinomas.

RPMA technology has also proved beneficial in investigating the cellular events that accompany metastatic progression, as exemplified by Paweletz et al [86] who used RPMAs to compare LCM-specimens of histologically normal prostate epithelium, prostate intraepithelial neoplasia, and invasive prostate cancer. Amplification of antibody-antigen complexes on the microarrays revealed a statistically significant increase in phosphorylation of Akt and a decrease in phosphorylation of Erk in premalignant and invasive prostate cancer. The authors draw a conclusion that these shifts in protein abundance indicated activation of pro-survival signaling pathways with cancer invasion. The same study also demonstrated that downstream components of the apoptotic cascade, namely cleaved and noncleaved caspase- 7 and PARP were also shifted towards prosurvival function during 
cancer progression [86]. Based on obtained data, the authors proposed a hypothetical model of prostate cancer progression according to which activation of Akt suppresses apoptosis, probably via inactivation of its substrate GSK3- $\beta$, which might cause an imbalance between cell proliferation and death leading to the accumulation of cells within prostate gland [86]. Simultaneously, transient ERK activation and turning on prosurvival pathways might be associated with cellular migration responsible for invasion. Akt seems to play a central role in prostate cancer metastasis, as its activation could foster cell motility and survival during stromal invasion.

Despite rapid development of proteomics technologies, cancer stem cell proteomics is still in its infancy. This could be ascribed to the extremely low availability of putative CSCs, as these cells represent only a small fraction of the overall cancer cell population. In addition, the methods for isolating a large enough sample of pure CSCs have not been developed yet [87]. However, recent proteomics studies on leukemic $[88,89]$ and pancreatic cancer stem cells [90] are bright examples on how to successfully overcome the issue of sample limitations in CSC research. Tibes at al. [88] demonstrated that RPMAs could be reliable, reproducible high-throughput approach for analyzing protein expression and phosphorylation status in primary acute myelogenous leukemia cells, cell lines and stem cells. Importantly, this group of authors found that leukemic stem cells had apparently different protein signature compared with normal stem cells, and observed different levels of protein expression when normal and leukemic CD34+/CD38+ and CD34+/CD38- cells were compared, or when leukemic and normal stem cells were compared. Novel perspective on human leukemogenesis was provided by Ota et al. [89], who utilized 2-DE/MS for protein profiling of isolated $\mathrm{AC}_{133^{+}}$leukemic blasts from 13 individuals with acute leukemia or related disorders. They detected 10 differentially expressed proteins including NuMA, heat shock proteins, and redox regulators. An over-expression of HSP70 family proteins in leukemic blasts was proposed to be directly associated with leukemogenesis, or to the development of drug resistance. Importantly, the finding that the abundance of the nuclear mitotic apparatus protein (NuMA) in leukemic blasts was related to the number of chromosomal abnormalities raised the possibility that over-expression of NuMA perturbs cell cycle progression by inhibiting mitosis resulting in the chromosomal instability. The finding that the forced expression of NuMA resulted in G2/M arrest and apoptosis clearly shows that some other genetic events, besides aberrant expression of NuMA, are required for malignant transformation to leukemic cells.

Characterization of the CSCs opens a new avenue for designing novel therapeutic strategies against cancer.
However, crucial to this task will be identification of specific cell surface antigens (markers) (Table 2) for CSCs detection and isolation from the heterogeneous tumor population. Hereby, membrane proteomics plays an important role, as demonstrated by He et al. [91], who employed the combination of lectin microarray and liquid chromatography-tandem mass spectrometry (LCMS/MS) to discover novel cell surface glycoprotein markers of a glioblastoma-derived stem-like cell line. These authors identified six differentially expressed proteins between the stem-like glioblastoma neurosphere culture and traditional adherent glioblastoma cell line, whereby receptor-type tyrosine-protein phosphatase zeta, Tenascin-C, Chondroitin sulfate proteoglycan NG2, Podocalyxin-like protein 1 and CD90 were up-regulated, and CD44 was down-regulated [91]. Further elucidation of the biological roles of these proteins might prove important for an early diagnosis and improved treatment of glioblastoma.

Although yielding many useful information on cancer invasiveness and progression, conventional genomic and proteomic platforms are still limited in their capacity to identify changes in protein activity caused by post-translational mechanisms [92]. Most proteomic techniques

Table 2 Representative cell surface markers for human cancer stem cells

\begin{tabular}{ll}
\hline Type of cancer stem cells & Cell surface markers \\
\hline Acute myelogenous leukemia; & CD34+, CD38-, CD44, CD123+ \\
Chronic myeloid leukemia & CD34+, CD38-, CD123+ \\
B-acute lymphogenous & CD34+, CD38-, CD19+ \\
leukemia & \\
Ph1-acute lymphogenous & CD34+, CD38- \\
leukemia & \\
Blast-crisis CML & CD34+, CD38+, CD123+ \\
Myeloproliferative disorder & CD117+ \\
Glioblastoma & CD133+ \\
Medulloblastoma & CD133+ \\
Pilocytic astrocytoma & CD133+ \\
Anaplastic ependymoma & CD133+ \\
Breast & CD44+, CD24 ${ }^{-l l o w}$, ESA+ \\
Prostate & CD133+/alpha 2 beta 1 integrin/CD44+ \\
& CD44+/CD24- \\
Ovarian cancer & CD44+, MyD88+ \\
Colon cancer & CD133+, CD44+, CD166+, E-CAMhig \\
Pancreatic cancer & CD133+, CD44+, CD24+ \\
Hepatocellular cancer & CD133+ \\
Head and neck squamous cell & CD44+ \\
carcinoma & Stro-1+, CD105+, CD44+ \\
Bone sarcomas & CD20+, CD133+ \\
Melanoma & CD133+ \\
Lung cancer & CD133+, CD90+ \\
Liver & CD133+ \\
Central nervous system & \\
\hline
\end{tabular}


provide information on protein abundance, which does not necessarily correlate with enzyme activity, since most enzymes are expressed as inactive zymogens or reside in complex with their endogenous inhibitors [93]. As an alternative, a new strategy termed activity-based protein profiling (ABPP) has emerged based on the use of enzyme family-specific activity-based chemical probes (ABPs) linked to specific reporter groups that by nature only target and subsequently tag the active form of these enzymes both in vitro and in vivo [94]. Jessani et al. [95] used this approach to profile serine hydrolase activities across a panel of human breast and melanoma cancer cell lines, and found that highly invasive cancer cells exerted secreted/membrane serine hydrolase activity profiles nearly orthogonal to those displayed by their less aggressive counterparts indicating that invasive cancers may share proteomic signatures that are more reflective of their cellular phenotype than tissue of origin. Importantly, they detected the up-regulation of two enzyme activities in invasive cancer lines, namely urokinase, a secreted serine protease with previously established role in tumor progression, and a membraneassociated serine hydrolase KIAA1363, the latter implicated as a new marker of tumor progression [95]. Similar study combining ABPP and metabolomics (rapid, high-throughput characterization of the small molecule metabolites including any metabolic intermediates, hormones and other components of signaling pathways found in an organism [96]) established a central role of KIAA1363 in an ether lipid signaling network bridging platelet-activating factor and lysophosphatidic acid [97]. As evident from these studies, integration of several different global profiling technologies may illuminate biochemical networks pertinent to cancer development and progression. In this respect, metabolomic profiling has already proved beneficial in characterizing the metabolic features of hepatocellular carcinoma [98], breast cancer [99], renal cell carcinoma [100] and prostate cancer [101] metastases. Metabolic alterations during cancer progression and metastasis revealed by these studies might provide new putative diagnostic and prognostic biomarkers as well as new therapeutic targets, such as e.g. sarcosine, an $N$-methyl derivative of glycine elevated most robustly in metastatic prostate cancer and detectable in the urine of men with organ-confined disease [101]. However, metabolic profiling studies involving CSCs to identify the key metabolites inherent to tumor progression are still scarce. The pioneering work in this field was performed at the American company Stemina Biomarker Discovery, whose scientists are focused on identifying metabolomic biomarkers that are potential indicators of drug efficacy against CSCs for the establishment of novel drug screening assays (http://www. stemina.com/web/publications.php). Specifically, they found small molecules unique to CSCs derived from glioblastoma multiforme (GBM), and identified unique metabolomic footprint of three different brain tumor stem cell lines (BTSC). Besides their potential as a screening tool for measuring GBM presence and progression, identified metabolite molecules might also serve as therapeutic targets in order to manufacture drugs specifically targeting GBM and BTSC cells.

\section{Conclusion}

Many hypotheses have been postulated to explain the intricate nature of the metastatic process, but none of them completely accounted for the actual biological and clinical observations. Consequently, metastasis still remains an open issue with only few metastasis-inducing proteins experimentally validated so far. Global scale proteomics studies undoubtedly revealed specific metastatic markers often related to cell-signalling processes; however, they proved to be patient-specific rather than type- or tumor stage-specific, which necessitates a need for individual therapeutic approach towards each patient.

Due to inconsistency between experimental results and clinical observations, a novel metastatic paradigm where serial and parallel metastatic processes are adequately integrated is needed to account for these differences. In addition, organ-tropic gene signatures were shown to bear a potential to improve patient risk stratification and therapeutic treatment. New diagnostic tools are therefore urgently required in clinical practice to detect patients who will benefit from the adjuvant chemotherapy after primary tumour resection. Consequently, this will lead to the improvements in patient treatment and reduction of adverse effects in patients who are traditionally unnecessarily treated with chemotherapy. While study of the metastases molecular mechanisms is far from trivial, the results discussed in this paper suggest that the benefits to our understanding of the cellular basis of metastasis more than justify the efforts employed.

\section{Acknowledgements}

This work was supported by the Foundation of Croatian Academy of Sciences and Arts and the Croatian Ministry of Science, Education and Sports (grants number 335-0982464-2393, 335-0000000-3532, 101-0982464-2277).

\section{Author details}

${ }^{1}$ Department of Biotechnology, University of Rijeka, 51000 Rijeka, Croatia. ${ }^{2}$ Division of Molecular Medicine, Rudjer Boskovic Institute, 10000 Zagreb, Croatia. ${ }^{3}$ Department of Internal Medicine, University Hospital "Sisters Of Mercy", 10000 Zagreb, Croatia. ${ }^{4}$ Croatian Academy of Sciences and Arts, Zrinski trg 11, 10000 Zagreb, Croatia.

\section{Authors' contributions}

SKP coordinated the preparation of the manuscript, designed the manuscript structure, performed the literature search, wrote the majority of manuscript text and prepared accompanying Figure 1 and Tables 1 and 2 . MS has been involved in extensive literature search, language revision, preparation of Tables 1 and 2 and wrote the majority of the section "Technological advances in metastasis research: proteomics". HB has been 
involved in literature search and revision of clinical aspects in the manuscript and wrote majority of section "Organ tropism and metastatic gene signature". SS contributed to the main manuscript idea, concept preparation, literature search and revised the final manuscript. KP proposed the manuscript idea, and has been involved in literature search, manuscript writing (in particular sections dealing with concept of cancer stem cells and molecular mechanisms underlying metastases), review of clinical aspects and final manuscript review.

All the authors read and approved the final manuscript.

\section{Competing interests}

The authors declare that they have no competing interests.

Received: 14 September 2010 Accepted: 22 February 2011

Published: 22 February 2011

\section{References}

1. Alizadeh AA, Eisen MB, Davis RE, Ma C, Lossos IS, Rosenwald A, Boldrick JC, Sabet H, Tran T, Yu X, Powell Jl, Yang L, Marti GE, Moore T, Hudson J Jr, Lu L, Lewis DB, Tibshirani R, Sherlock G, Chan WC, Greiner TC, Weisenburger DD, Armitage JO, Warnke R, Levy R, Wilson W, Grever MR, Byrd JC, Botstein D, Brown PO, Staudt LM: Distinct types of diffuse large B-cell lymphoma identified by gene expression profiling. Nature 2000, 403:503-511.

2. Chung $\mathrm{CH}$, Bernard PS, Perou CM: Molecular portraits and the family tree of cancer. Nat Genet 2002, 32(Suppl):533-540.

3. Staudt LM: Gene expression profiling of lymphoid malignancies. Annu Rev Med 2002, 53:303-318.

4. van 't Veer $L$, Dai $H$, van de Vijver MJ, He YD, Hart AA, Mao M, Peterse HL, van der Kooy K, Marton MJ, Witteveen AT, Schreiber GJ, Kerkhoven RM, Roberts C, Linsley PS, Bernards R, Friend SH: Gene expression profiling predicts clinical outcome of breast cancer. Nature 2002, 415:530-536.

5. Schulenburg A, Bramswig K, Herrmann H, Karlic H, Mirkina I, Hubmann R, Laffer S, Marian B, Shehata M, Krepler C, Pehamberger H, Grunt T, Jager U, Zielinski CC, Valent P: Neoplastic stem cells: current concepts and clinical perspectives. Crit Rev Oncol Hematol 76:79-98.

6. Kitamura H, Okudela K, Yazawa T, Sato H, Shimoyamada H: Cancer stem cell: implications in cancer biology and therapy with special reference to lung cancer. Lung Cancer 2009, 66:275-281.

7. Reya T, Morrison SJ, Clarke MF, Weissman IL: Stem cells, cancer, and cancer stem cells. Nature 2001, 414:105-111.

8. Wicha MS, Liu S, Dontu G: Cancer stem cells: an old idea-a paradigm shift. Cancer Res 2006, 66:1883-1890, discussion 1895-1886.

9. Li Y, Welm B, Podsypanina K, Huang S, Chamorro M, Zhang X, Rowlands T, Egeblad M, Cowin P, Werb Z, Tan LK, Rosen JM, Varmus HE: Evidence that transgenes encoding components of the Wnt signaling pathway preferentially induce mammary cancers from progenitor cells. Proc Natl Acad Sci USA 2003, 100:15853-15858.

10. Zhang XH, Wang Q, Gerald W, Hudis CA, Norton L, Smid M, Foekens JA Massague J: Latent bone metastasis in breast cancer tied to Srcdependent survival signals. Cancer Cell 2009, 16:67-78.

11. Nguyen DX, Massague J: Genetic determinants of cancer metastasis. Nat Rev Genet 2007, 8:341-352.

12. Madani I, De Neve W, Mareel M: Does ionizing radiation stimulate cancer invasion and metastasis? Bull Cancer 2008, 95:292-300.

13. Kurrey NK, Jalgaonkar SP, Joglekar AV, Ghanate AD, Chaskar PD, Doiphode RY, Bapat SA: Snail and slug mediate radioresistance and chemoresistance by antagonizing p53-mediated apoptosis and acquiring a stem-like phenotype in ovarian cancer cells. Stem Cells 2009, 27:2059-2068.

14. Tanei T, Morimoto K, Shimazu K, Kim SJ, Tanji Y, Taguchi T, Tamaki Y, Noguchi S: Association of breast cancer stem cells identified by aldehyde dehydrogenase 1 expression with resistance to sequential Paclitaxel and epirubicin-based chemotherapy for breast cancers. Clin Cancer Res 2009, 15:4234-4241.

15. Dean M, Fojo T, Bates S: Tumour stem cells and drug resistance. Nat Rev Cancer 2005, 5:275-284

16. Gray JW: Evidence emerges for early metastasis and parallel evolution of primary and metastatic tumors. Cancer Cell 2003, 4:4-6.

17. Al-Mulla F, Keith WN, Pickford IR, Going JJ, Birnie GD: Comparative genomic hybridization analysis of primary colorectal carcinomas and their synchronous metastases. Genes Chromosomes Cancer 1999, 24:306-314.
18. Bissig H, Richter J, Desper R, Meier V, Schraml P, Schaffer AA, Sauter G, Mihatsch MJ, Moch $\mathrm{H}$ : Evaluation of the clonal relationship between primary and metastatic renal cell carcinoma by comparative genomic hybridization. Am J Pathol 1999, 155:267-274.

19. Hovey RM, Chu L, Balazs M, DeVries S, Moore D, Sauter G, Carroll PR, Waldman FM: Genetic alterations in primary bladder cancers and their metastases. Cancer Res 1998, 58:3555-3560.

20. Kuukasjarvi T, Karhu R, Tanner M, Kahkonen M, Schaffer A, Nupponen N, Pennanen S, Kallioniemi A, Kallioniemi OP, Isola J: Genetic heterogeneity and clonal evolution underlying development of asynchronous metastasis in human breast cancer. Cancer Res 1997, 57:1597-1604.

21. Pandis N, Teixeira MR, Adeyinka A, Rizou H, Bardi G, Mertens F, Andersen JA, Bondeson L, Sfikas K, Qvist H, Apostolikas N, Mitelman F, Heim S: Cytogenetic comparison of primary tumors and lymph node metastases in breast cancer patients. Genes Chromosomes Cancer 1998, 22:122-129.

22. Ma XJ, Salunga R, Tuggle JT, Gaudet J, Enright E, McQuary P, Payette T, Pistone M, Stecker K, Zhang BM, Zhou YX, Varnholt H, Smith B, Gadd M, Chatfield E, Kessler J, Baer TM, Erlander MG, Sgroi DC: Gene expression profiles of human breast cancer progression. Proc Natl Acad Sci USA 2003, 100:5974-5979.

23. Perou CM, Sorlie T, Eisen MB, van de Rijn M, Jeffrey SS, Rees CA, Pollack JR, Ross DT, Johnsen H, Akslen LA, Fluge O, Pergamenschikov A, Williams C, Zhu SX, Lonning PE, Borresen-Dale AL, Brown PO, Botstein D: Molecular portraits of human breast tumours. Nature 2000, 406:747-752.

24. Porter D, Lahti-Domenici J, Keshaviah A, Bae YK, Argani P, Marks J Richardson A, Cooper A, Strausberg R, Riggins GJ, Schnitt S, Gabrielson E, Gelman R, Polyak K: Molecular markers in ductal carcinoma in situ of the breast. Mol Cancer Res 2003, 1:362-375.

25. Schmidt-Kittler O, Ragg T, Daskalakis A, Granzow M, Ahr A, Blankenstein TJ, Kaufmann M, Diebold J, Arnholdt H, Muller P, Bischoff J, Harich D, Schlimok G, Riethmuller G, Eils R, Klein CA: From latent disseminated cells to overt metastasis: genetic analysis of systemic breast cancer progression. Proc Natl Acad Sci USA 2003, 100:7737-7742

26. Husemann $Y$, Geigl JB, Schubert F, Musiani P, Meyer M, Burghart E, Forni G, Eils R, Fehm T, Riethmuller G, Klein CA: Systemic spread is an early step in breast cancer. Cancer Cell 2008, 13:58-68.

27. Singh SK, Hawkins C, Clarke ID, Squire JA, Bayani J, Hide T, Henkelman RM, Cusimano MD, Dirks PB: Identification of human brain tumour initiating cells. Nature 2004, 432:396-401.

28. Dontu G, Al-Hajj M, Abdallah WM, Clarke MF, Wicha MS: Stem cells in normal breast development and breast cancer. Cell Prolif 2003, 36(Suppl 1):59-72.

29. Lapidot T, Pflumio F, Doedens M, Murdoch B, Williams DE, Dick JE: Cytokine stimulation of multilineage hematopoiesis from immature human cells engrafted in SCID mice. Science 1992, 255:1137-1141.

30. Thiery JP: Epithelial-mesenchymal transitions in tumour progression. Nat Rev Cancer 2002, 2:442-454

31. Karnoub AE, Dash AB, Vo AP, Sullivan A, Brooks MW, Bell GW, Richardson AL, Polyak K, Tubo R, Weinberg RA: Mesenchymal stem cells within tumour stroma promote breast cancer metastasis. Nature 2007, 449:557-563.

32. Mani SA, Guo W, Liao MJ, Eaton EN, Ayyanan A, Zhou AY, Brooks M, Reinhard F, Zhang CC, Shipitsin M, Campbell LL, Polyak K, Brisken C, Yang J, Weinberg RA: The epithelial-mesenchymal transition generates cells with properties of stem cells. Cell 2008, 133:704-715.

33. Hurt EM, Farrar WL: Cancer stem cells: the seeds of metastasis? Mol Interv 2008, 8:140-142.

34. Condeelis J, Segall JE: Intravital imaging of cell movement in tumours. Nat Rev Cancer 2003, 3:921-930.

35. Lu X, Kang Y: Discovery of bone metastasis genes by functional genomics. PharmDD 2005, 5:32-35.

36. Hiratsuka S, Nakamura K, Iwai S, Murakami M, Itoh T, Kijima H, Shipley JM, Senior RM, Shibuya M: MMP9 induction by vascular endothelial growth factor receptor-1 is involved in lung-specific metastasis. Cancer Cell 2002, 2:289-300.

37. Kaplan RN, Rafii S, Lyden D: Preparing the "soil": the premetastatic niche. Cancer Res 2006, 66:11089-11093.

38. Kang Y, Siegel PM, Shu W, Drobnjak M, Kakonen SM, Cordon-Cardo C, Guise TA, Massague J: A multigenic program mediating breast cancer metastasis to bone. Cancer Cell 2003, 3:537-549.

39. Kakiuchi S, Daigo Y, Tsunoda T, Yano S, Sone S, Nakamura Y: Genome-wide analysis of organ-preferential metastasis of human small cell lung cancer in mice. Mol Cancer Res 2003, 1:485-499. 
40. Minn AJ, Gupta GP, Siegel PM, Bos PD, Shu W, Giri DD, Viale A, Olshen AB, Gerald WL, Massague J: Genes that mediate breast cancer metastasis to lung. Nature 2005, 436:518-524.

41. Ramaswamy S: Cancer transcriptomics: modeling metastasis. Eur J Hum Genet 2006, 14:1-2.

42. Sorlie T, Perou CM, Tibshirani R, Aas T, Geisler S, Johnsen H, Hastie T, Eisen MB, van de Rijn M, Jeffrey SS, Thorsen T, Quist H, Matese JC, Brown PO, Botstein D, Eystein Lonning P, Borresen-Dale AL: Gene expression patterns of breast carcinomas distinguish tumor subclasses with clinical implications. Proc Natl Acad Sci USA 2001, 98:10869-10874.

43. van de Vijver MJ, He YD, van't Veer $L$, Dai H, Hart AA, Voskuil DW, Schreiber GJ, Peterse JL, Roberts C, Marton MJ, Parrish M, Atsma D, Witteveen A, Glas A, Delahaye L, van der Velde T, Bartelink H, Rodenhuis S, Rutgers ET, Friend SH, Bernards R: A gene-expression signature as a predictor of survival in breast cancer. N Engl J Med 2002, 347:1999-2009.

44. Ramaswamy S, Ross KN, Lander ES, Golub TR: A molecular signature of metastasis in primary solid tumors. Nat Genet 2003, 33:49-54.

45. Bernards R, Weinberg RA: A progression puzzle. Nature 2002, 418:823

46. Hunter K, Welch DR, Liu ET: Genetic background is an important determinant of metastatic potential. Nat Genet 2003, 34:23-24, author reply 25 .

47. Kucia M, Reca R, Miekus K, Wanzeck J, Wojakowski W, JanowskaWieczorek A, Ratajczak J, Ratajczak MZ: Trafficking of normal stem cells and metastasis of cancer stem cells involve similar mechanisms: pivotal role of the SDF-1-CXCR4 axis. Stem Cells 2005, 23:879-894.

48. Muller A, Homey B, Soto H, Ge N, Catron D, Buchanan ME, McClanahan T, Murphy E, Yuan W, Wagner SN, Barrera JL, Mohar A, Verastegui E, Zlotnik A: Involvement of chemokine receptors in breast cancer metastasis. Nature 2001, 410:50-56.

49. Hunter KW, Crawford NP, Alsarraj J: Mechanisms of metastasis. Breast Cancer Res 2008, 10(Suppl 1):S2.

50. Huber MA, Kraut N, Beug H: Molecular requirements for epithelialmesenchymal transition during tumor progression. Curr Opin Cell Biol 2005, 17:548-558.

51. Stupack DG, Teitz T, Potter MD, Mikolon D, Houghton PJ, Kidd VJ, Lahti JM, Cheresh DA: Potentiation of neuroblastoma metastasis by loss of caspase-8. Nature 2006, 439:95-99.

52. Gupta GP, Nguyen DX, Chiang AC, Bos PD, Kim JY, Nadal C, Gomis RR, Manova-Todorova K, Massague J: Mediators of vascular remodelling coopted for sequential steps in lung metastasis. Nature 2007, 446:765-770.

53. Hu M, Yao J, Carroll DK, Weremowicz S, Chen H, Carrasco D, Richardson A, Violette S, Nikolskaya T, Nikolsky Y, Bauerlein EL, Hahn WC, Gelman RS, Allred C, Bissell MJ, Schnitt S, Polyak K: Regulation of in situ to invasive breast carcinoma transition. Cancer Cell 2008, 13:394-406.

54. Riethmuller G, Klein CA: Early cancer cell dissemination and late metastatic relapse: clinical reflections and biological approaches to the dormancy problem in patients. Semin Cancer Biol 2001, 11:307-311.

55. Harris JF, Chambers AF, Hill RP, Ling V: Metastatic variants are generated spontaneously at a high rate in mouse KHT tumor. Proc Natl Acad Sci USA 1982, 79:5547-5551.

56. Ling V, Chambers AF, Harris JF, Hill RP: Dynamic heterogeneity and metastasis. J Cell Physiol Supp/ 1984, 3:99-103.

57. Weiss L: Metastatic inefficiency. Adv Cancer Res 1990, 54:159-211.

58. Pawelek JM: Tumour-cell fusion as a source of myeloid traits in cancer. Lancet Oncol 2005, 6:988-993.

59. Pawelek JM: Cancer-cell fusion with migratory bone-marrow-derived cells as an explanation for metastasis: new therapeutic paradigms. Future Oncol 2008, 4:449-452.

60. Bjerkvig R, Tysnes BB, Aboody KS, Najbauer J, Terzis AJ: Opinion: the origin of the cancer stem cell: current controversies and new insights. Nat Rev Cancer 2005, 5:899-904

61. De Baetselier P, Roos E, Brys L, Remels L, Feldman M: Generation of invasive and metastatic variants of a non-metastatic T-cell lymphoma by in vivo fusion with normal host cells. Int J Cancer 1984, 34:731-738.

62. Miller FR, Mohamed AN, McEachern D: Production of a more aggressive tumor cell variant by spontaneous fusion of two mouse tumor subpopulations. Cancer Res 1989, 49:4316-4321.

63. Goldenberg DM, Pavia RA, Tsao MC: In vivo hybridisation of human tumour and normal hamster cells. Nature 1974, 250:649-651.
64. Chakraborty AK, Sodi S, Rachkovsky M, Kolesnikova N, Platt JT, Bolognia JL, Pawelek JM: A spontaneous murine melanoma lung metastasis comprised of host $x$ tumor hybrids. Cancer Res 2000, 60:2512-2519.

65. Hida K, Hida Y, Amin DN, Flint AF, Panigrahy D, Morton CC, Klagsbrun M: Tumor-associated endothelial cells with cytogenetic abnormalities. Cancer Res 2004, 64:8249-8255.

66. Espina V, Dettloff KA, Cowherd S, Petricoin EF, Liotta LA: Use of proteomic analysis to monitor responses to biological therapies. Expert Opin Biol Ther 2004, 4:83-93.

67. Wang JW, Peng SY, Li JT, Wang Y, Zhang ZP, Cheng Y, Cheng DQ, Weng WH, Wu XS, Fei XZ, Quan ZW, Li JY, Li SG, Liu YB: Identification of metastasis-associated proteins involved in gallbladder carcinoma metastasis by proteomic analysis and functional exploration of chloride intracellular channel 1. Cancer Lett 2009, 281:71-81.

68. Chen CD, Wang CS, Huang YH, Chien KY, Liang Y, Chen WJ, Lin KH: Overexpression of CLIC1 in human gastric carcinoma and its clinicopathological significance. Proteomics 2007, 7:155-167.

69. Tian T, Hao J, Xu A, Luo C, Liu C, Huang L, Xiao X, He D: Determination of metastasis-associated proteins in non-small cell lung cancer by comparative proteomic analysis. Cancer Sci 2007, 98:1265-1274.

70. Song HY, Liu YK, Feng JT, Cui JF, Dai Z, Zhang LJ, Feng JX, Shen HL, Tang ZY: Proteomic analysis on metastasis-associated proteins of human hepatocellular carcinoma tissues. J Cancer Res Clin Oncol 2006, 132:92-98

71. Wang G, Wang X, Wang S, Song H, Sun H, Yuan W, Cao B, Bai J, Fu S: Colorectal cancer progression correlates with upregulation of S100A11 expression in tumor tissues. Int J Colorectal Dis 2008, 23:675-682.

72. Pang J, Liu WP, Liu XP, Li LY, Fang YQ, Sun QP, Liu SJ, Li MT, Su ZL, Gao X: Profiling protein markers associated with lymph node metastasis in prostate cancer by DIGE-based proteomics analysis. J Proteome Res 9:216-226.

73. Adamson J, Morgan EA, Beesley C, Mei Y, Foster CS, Fujii H, Rudland PS, Smith $\mathrm{PH}, \mathrm{Ke} Y$ : High-level expression of cutaneous fatty acid-binding protein in prostatic carcinomas and its effect on tumorigenicity. Oncogene 2003, 22:2739-2749.

74. Jing C, Beesley C, Foster CS, Chen H, Rudland PS, West DC, Fujii H, Smith $\mathrm{PH}$, Ke Y: Human cutaneous fatty acid-binding protein induces metastasis by up-regulating the expression of vascular endothelial growth factor gene in rat Rama 37 model cells. Cancer Res 2001, 61:4357-4364.

75. Yao H, Zhang Z, Xiao Z, Chen Y, Li C, Zhang P, Li M, Liu Y, Guan Y, Yu Y, Chen $Z$ : Identification of metastasis associated proteins in human lung squamous carcinoma using two-dimensional difference gel electrophoresis and laser capture microdissection. Lung Cancer 2009, 65:41-48.

76. Cheng L, Zhou L, Tao L, Zhang M, Cui J, Li Y: SELDI-TOF MS profiling of serum for detection of laryngeal squamous cell carcinoma and the progression to lymph node metastasis. J Cancer Res Clin Oncol 2008, 134:769-776.

77. Zheng GX, Wang CX, Qu X, Deng XM, Deng BP, Zhang J: Establishment of serum protein pattern for screening colorectal cancer using SELDI-TOFMS. Exp Oncol 2006, 28:282-287.

78. Zheng Z, Gao Y, Gu L, Mou H, Zhu C, Zhu J, Xu S: Discovery of metastasisassociated biomarkers in ovarian cancer using SELDI-TOF: An in vitro and clinical study. Clin Oncol Cancer Res 2009, 6:317-321.

79. SongWei D, XiaoMin W, LiYun L, JiFu L, ShanShan W, LingYun H, XueYuan X, DaCheng H: Discovery and identification of Serum Amyloid A protein elevated in lung cancer serum. Sci China C Life Sci 2007, 50:305-311.

80. Kohli M, Siegel E, Bhattacharya S, Khan MA, Shah R, Suva LJ: Surfaceenhanced laser desorption/ionization time-of-flight mass spectrometry (SELDI-TOF MS) for determining prognosis in advanced stage hormone relapsing prostate cancer. Cancer Biomarkers 2007, 2:249-258.

81. Brozkova K, Budinska E, Bouchal P, Hernychova L, Knoflickova D, Valik D, Vyzula R, Vojtesek B, Nenutil R: Surface-enhanced laser desorption/ ionization time-of-flight proteomic profiling of breast carcinomas identifies clinicopathologically relevant groups of patients similar to previously defined clusters from cDNA expression. Breast Cancer Res 2008, 10:R48. 
82. Lu HB, Zhou JH, Ma YY, Lu HL, Tang YL, Zhang QY, Zhao CH: Five serum proteins identified using SELDI-TOF-MS as potential biomarkers of gastric cancer. Jpn J Clin Oncol 40:336-342.

83. Goncalves A, Esterni B, Bertucci F, Sauvan R, Chabannon C, Cubizolles M, Bardou VJ, Houvenaegel G, Jacquemier J, Granjeaud S, Meng XY, Fung ET, Birnbaum D, Maraninchi D, Viens P, Borg JP: Postoperative serum proteomic profiles may predict metastatic relapse in high-risk primary breast cancer patients receiving adjuvant chemotherapy. Oncogene 2006, 25:981-989.

84. Cowherd SM, Espina VA, Petricoin EF, Liotta LA: Proteomic analysis of human breast cancer tissue with laser-capture microdissection and reverse-phase protein microarrays. Clin Breast Cancer 2004, 5:385-392.

85. Sheehan KM, Calvert VS, Kay EW, Lu Y, Fishman D, Espina V, Aquino J, Speer R, Araujo R, Mills GB, Liotta LA, Petricoin EF, Wulfkuhle JD: Use of reverse phase protein microarrays and reference standard development for molecular network analysis of metastatic ovarian carcinoma. Mol Cell Proteomics 2005, 4:346-355.

86. Paweletz CP, Charboneau L, Bichsel VE, Simone NL, Chen T, Gillespie JW Emmert-Buck MR, Roth MJ, Petricoin IE, Liotta LA: Reverse phase protein microarrays which capture disease progression show activation of prosurvival pathways at the cancer invasion front. Oncogene 2001, 20:1981-1989.

87. Nishizuka S: Profiling cancer stem cells using protein array technology. Eur J Cancer 2006, 42:1273-1282.

88. Tibes R, Qiu Y, Lu Y, Hennessy B, Andreeff M, Mills GB, Kornblau SM: Reverse phase protein array: validation of a novel proteomic technology and utility for analysis of primary leukemia specimens and hematopoietic stem cells. Mol Cancer Ther 2006, 5:2512-2521.

89. Ota J, Yamashita Y, Okawa K, Kisanuki H, Fujiwara S, Ishikawa M, Lim Choi Y, Ueno S, Ohki R, Koinuma K, Wada T, Compton D, Kadoya T, Mano H: Proteomic analysis of hematopoietic stem cell-like fractions in leukemic disorders. Oncogene 2003, 22:5720-5728.

90. Dai L, Li C, Shedden KA, Lee CJ, Quoc H, Simeone DM, Lubman DM: Quantitative proteomic profiling studies of pancreatic cancer stem cells. J Proteome Res 9:3394-3402.

91. He J, Liu Y, Xie X, Zhu T, Soules M, DiMeco F, Vescovi AL, Fan X, Lubman DM: Identification of cell surface glycoprotein markers for glioblastoma-derived stem-like cells using a lectin microarray and LCMS/MS approach. J Proteome Res 9:2565-2572.

92. Nomura DK, Dix MM, Cravatt BF: Activity-based protein profiling for biochemical pathway discovery in cancer. Nat Rev Cancer 10:630-638.

93. Paulick MG, Bogyo M: Application of activity-based probes to the study of enzymes involved in cancer progression. Curr Opin Genet Dev 2008, 18:97-106

94. Walls C, Zhou B, Zhang ZY: Activity-based protein profiling of protein tyrosine phosphatases. Methods Mol Biol 2009, 519:417-429.

95. Jessani $N$, Liu Y, Humphrey M, Cravatt BF: Enzyme activity profiles of the secreted and membrane proteome that depict cancer cell invasiveness. Proc Natl Acad Sci USA 2002, 99:10335-10340.

96. Vinayavekhin N, Homan EA, Saghatelian A: Exploring disease through metabolomics. ACS Chem Biol 5:91-103.

97. Chiang KP, Niessen S, Saghatelian A, Cravatt BF: An enzyme that regulates ether lipid signaling pathways in cancer annotated by multidimensional profiling. Chem Biol 2006, 13:1041-1050.

98. Wang J, Zhang S, Li Z, Yang J, Huang C, Liang R, Liu Z, Zhou R: (1)H-NMRbased metabolomics of tumor tissue for the metabolic characterization of rat hepatocellular carcinoma formation and metastasis. Tumour Biol 2010, 32:223-231.

99. Lu X, Bennet B, Mu E, Rabinowitz J, Kang Y: Metabolomic changes accompanying transformation and acquisition of metastatic potential in a syngeneic mouse mammary tumor model. J Biol Chem 285:9317-9321.

100. Catchpole G, Platzer A, Weikert C, Kempkensteffen C, Johannsen M, Krause H, Jung K, Miller K, Willmitzer L, Selbig J, Weikert S: Metabolic profiling reveals key metabolic features of renal cell carcinoma. J Cell Mol Med 2009, 15:109-118.

101. Sreekumar A, Poisson LM, Rajendiran TM, Khan AP, Cao Q, Yu J, Laxman B, Mehra R, Lonigro RJ, Li Y, Nyati MK, Ahsan A, Kalyana-Sundaram S, Han B, Cao X, Byun J, Omenn GS, Ghosh D, Pennathur S, Alexander DC, Berger A, Shuster JR, Wei JT, Varambally S, Beecher C, Chinnaiyan AM: Metabolomic profiles delineate potential role for sarcosine in prostate cancer progression. Nature 2009, 457:910-914. doi:10.1186/1476-4598-10-22

Cite this article as: Kraljevic Pavelic et al:: Metastasis: new perspectives on an old problem. Molecular Cancer 2011 10:22.

\section{Submit your next manuscript to BioMed Central and take full advantage of:}

- Convenient online submission

- Thorough peer review

- No space constraints or color figure charges

- Immediate publication on acceptance

- Inclusion in PubMed, CAS, Scopus and Google Scholar

- Research which is freely available for redistribution 